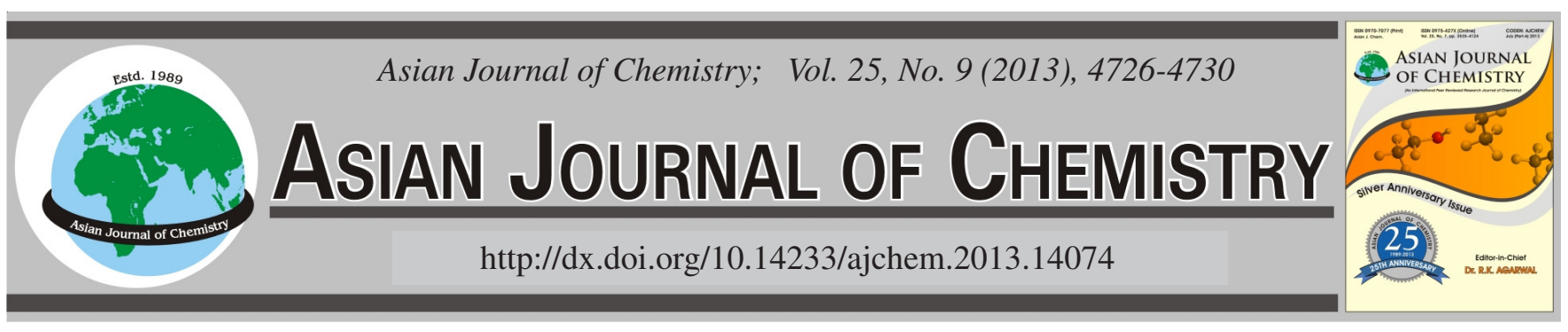

\title{
Efficiency of Urban Wetlands in Removing Agricultural Non-point Source Pollution
}

\author{
Y.B. ReN ${ }^{1}$, N.Q. REN ${ }^{1, *}$, X.K. $\mathrm{LI}^{2}$ and J.G. $\mathrm{LI}^{1}$
}

${ }^{1}$ State Key Laboratory of Urban Water Resource and Environment, Harbin Institute of Technology, Harbin 150090, P.R. China

${ }^{2}$ Harbin City People's Government Laboratory, Harbin 150028, P.R. China

*Corresponding author: Fax: +86 451 53925800; Tel: +86 15804624727; E-mail: yirenyiyun@163.com

(Received: 21 May 2012;

Accepted: 4 March 2013)

AJC-13058

\begin{abstract}
In this study, field monitoring together with laboratory analysis were conducted to investigate the efficiency of urban wetlands in removing agricultural non-point source pollution. The urban wetland and two neighboring farmland in Wanbao County, Songbei district, Harbin city of China was selected as target field and seasonal variation of the agricultural non-point source pollution in wetland water body and agricultural runoff was also determined. Results showed that the concentration of the agricultural non-point source pollutants in the water body of wetland decreased substantially after purification by the wetland, which was lower than that in the farmland runoff. The concentrations of total nitrogen, $\mathrm{NO}_{3}-\mathrm{N}, \mathrm{NH}_{4}{ }^{+}-\mathrm{N}$ and total phosphorus decreased by $74.22,50.38,77.94$ and $17.91 \%$ respectively, indicating that urban wetlands can intercept and remove agricultural non-point source pollutants effectively. In seasonal changes, total nitrogen and $\mathrm{NO}_{3}-\mathrm{N}$ concentration increased first and then decreased reaching the highest value in May; the concentrations of $\mathrm{NH}_{4}{ }^{+}-\mathrm{N}_{\text {reached the highest }}$ value in October; the highest total phosphorus concentration was found in August.
\end{abstract}

Key Words: Urban wetland, Removal efficiency, Agricultural non-point pollution.

\section{INTRODUCTION}

Agricultural non-point source pollution has become one of the main causes of river and lake water body eutrophication $^{1,2}$, which has drawn much attention by both scientific and regulatory communities. Nitrogen and phosphorus are the two main factors that contribute to the eutrophication. Thus, removal of the $\mathrm{N}$ and $\mathrm{P}$ from water has been a hot topic of research. Wetland, an ecosystem composed of plants, substrates and microorganisms, has been an alternative for pollution control in many regions in the world. It has been used for water purification in rivers ${ }^{3}$, lakes ${ }^{4}$, industrial wastewater treatment $^{5,6}$, urban rainstorm runoff pollution ${ }^{7,8}$ and agricultural non-point source pollution control ${ }^{9,10}$. For instance, nitrogen and phosphorus nutrient removal ability of natural wetlands and artificial wetlands has been investigated ${ }^{11}$ and the effect of a number of factors such as plant absorption ${ }^{12-14}$ and biotransformation on the migration of nitrogen and phosphorus in the wetland ecological system has been analyzed. The absorption effect of various kinds of wetland plants ${ }^{16-18}$ and their different growth patterns ${ }^{19}$ and growth periods ${ }^{20}$ on agricultural nonpoint source pollution was also studied.

Current study on wetlands purifying agricultural non-point source pollution was mainly focused on the purification mechanism of wetland ${ }^{21}$ and the absorption ability of plants in artificial wetlands ${ }^{22}$, while little information is available on the urban wetlands in purifying agricultural non-point source pollution, especially produced by rainfall-runoff ${ }^{23-25}$. In this study, an urban wetland with two neighboring farmland were selected as target field and the removal and interception of nitrogen and phosphorus by wetlands, combined with seasonal variation of $\mathrm{N}$ and $\mathrm{P}$ in the wetland water and runoff were determined. The result from this study would provide a theoretical basis for urban wetlands intercepting non-point source pollutants and have great significance for protecting the surface water.

\section{EXPERIMENTAL}

The urban wetland and two neighboring farmlands located in Wanbao County, Songbei District, Harbin City of China. Produced rainfall runoff was directly discharged into the farmlands. One farmland, covering an area of $3000 \mathrm{~m}^{2}$, was designated as land no.1. The other one, located in the large stretch of rural cultivated land near the wetland was designated as land no.2.Rainfall runoff was collected in October 2004, May 2005, August 2005, April 2008 and May, 2008 to study the effect of the wetland on farmland runoff pollutants and seasonal changes of pollutants.

Before the rainfall, three sides of the farmland on the slightly higher terrain were enclosed to form a semi-closed rectangular $1 \mathrm{~m} \times 5 \mathrm{~m}$ plot with bamboo sticks and plastic 


\begin{tabular}{|c|c|c|c|c|c|c|c|}
\hline \multirow{3}{*}{\multicolumn{2}{|c|}{ Project }} & \multicolumn{6}{|c|}{$\begin{array}{c}\text { TABLE-1 } \\
\text { AMPLED DATA OF RUNOFF IN FARMLAND EXPERIMENTAL AREA }\end{array}$} \\
\hline & & \multicolumn{2}{|c|}{ No.1 Experimental plot collection tank } & \multicolumn{2}{|c|}{ No.2 Experimental plot collection tank } & \multicolumn{2}{|c|}{ Mixed (averaged) } \\
\hline & & No. 1 & No. 2 & No. 1 & No. 2 & No. 1 & No. 2 \\
\hline \multicolumn{2}{|c|}{ Runoff amount (mL) } & 3000 & 3100 & 2500 & 2300 & 6100 & 4800 \\
\hline \multirow{4}{*}{$\begin{array}{l}\text { Pollutant } \\
\text { concentration } \\
(\mathrm{mg} / \mathrm{L})\end{array}$} & Total nitrogen & 9.19 & 12.65 & 11.84 & 12.86 & 10.95 & 12.33 \\
\hline & $\mathrm{NO}_{3}-\mathrm{N}$ & 2.73 & 3.61 & 3.63 & 5.07 & 3.18 & 4.32 \\
\hline & $\mathrm{NH}_{4}^{+}-\mathrm{N}$ & 1.97 & 2.19 & 2.58 & 3.89 & 2.08 & 3.21 \\
\hline & Total phosphorus & 1.01 & 0.79 & 0.917 & 1.32 & 0.90 & 1.11 \\
\hline
\end{tabular}

sheets, which were $50 \mathrm{~cm}$ above the ground, cutting off the runoff within the experimental area from the outside. Two rectangular $100 \mathrm{~cm} \times 50 \mathrm{~cm} \times 50 \mathrm{~cm}$ runoff catchments were used as collection tanks. Plastic coated water-proof high density polyethylene woven cloth was laid properly inside the tanks to prevent collected runoff from penetrating into the soil and asbestos tiles were used to cover the top of the tanks to prevent the rainfall and runoff outside the plot from flowing into the collection tanks. The runoff amount was determined as the average runoff of two collection tanks and the concentration of pollutants was determined from the mixture concentration of two collection tanks. Water in wetlands and runoff in the collection tanks were collected four hours after rainfall and analyzed for pollutants.

RESULTS AND DISCUSSION

Rainfall-runoff pollutant interception by the wetland: The removal of nitrogen by wetlands is realized mainly through plant absorption and nitrification and de-nitrification ${ }^{26}$. Agricultural non-point source pollution is mostly loaded in the rainwater runoff. The fertilization amount and time of farmlands has an important effect on the load ${ }^{27}$ of non-point source pollution. The interception of pollutants by urban wetland was conducted in late May, 2008. A rainfall began around 3:25 p.m., May $29^{\text {th }}, 2008$, raining heavily at the beginning and produced runoff at 3:35 p.m. The rain became weak around 4:20 p.m. and stopped at 5:49 p.m., lasting for $2 \mathrm{~h}$ and $24 \mathrm{~min}$. After the rainfall, the runoff amount from the two collection tanks was measured respectively in the field. The mixture of runoff samples from two tanks was used to determine pollutants concentration. Table-1 listed some measured parameters.

After the rain stopped, the runoff amount of the whole experimental area was estimated by the amount of collected run off $\times$ the size of the farmland experimental area and the total mass of the pollutants produced in the farmland experimental area was obtained by the measured pollutant concentration $\times$ runoff amount. Based on the above-stated method, the amount of pollutants produced after a certain rainfall in the two neighboring farmlands that were intercepted by Songbei Wetland was calculated.

Effect of the wetland in removing rainfall-runoff pollutants: Land No. 2 was selected as the experimental area, where the change in the concentration of total nitrogen and total phosphorus was monitored in the whole rainfall process on May $29^{\text {th }}, 2008$. The rainfall lasted $2 \mathrm{~h}$ and $24 \mathrm{~min}$ and samples were collected every $10 \mathrm{~min}$. The runoff concentrations of total nitrogen and total phosphorus were shown in Figs. 1 and 2. At the initial rainfall-runoff formation stage, total nitrogen concentration value was high and began to fall about an hour later. The peak value of total nitrogen appeared at 55 min after the runoff was formed and the peak value of total phosphorus appeared at $25 \mathrm{~min}$ after the runoff was formed, then followed by a wavy descent.

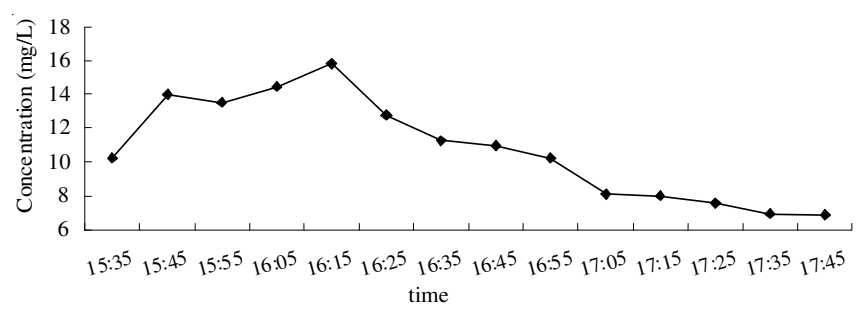

Fig. 1. Change curve of total nitrogen concentration in the rainfall-runoff process

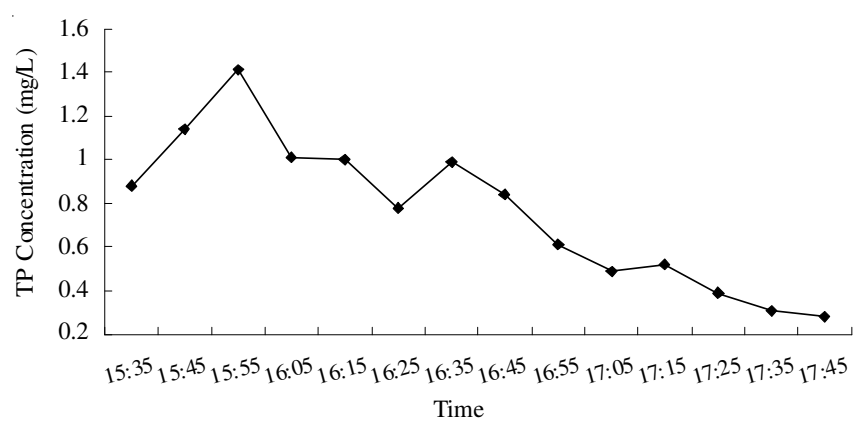

Fig. 2. Change curve of total phosphorus concentration in the rainfall-runoff process

As can be seen in Fig. 1, the initial concentration of total nitrogen in the runoff was $10.23 \mathrm{mg} / \mathrm{L}$ and reached the highest value of $15.81 \mathrm{mg} / \mathrm{L}$ at $50 \mathrm{~min}$ after rainfall, followed by a wavy change, showing a general downward trend. Fig. 2 showed that the initial concentration of total phosphorus was $0.88 \mathrm{mg} / \mathrm{L}$ and reached the highest value of $1.14 \mathrm{mg} / \mathrm{L}$ at 20 min after rainfall-runoff was formed and then followed by a wavy downward trend. The output concentration of total phosphorus was $0.28 \mathrm{mg} / \mathrm{L}$, significantly reduced compared with the concentration produced at the initial runoff formation stage.

After the rain stopped, sample collection and monitoring of the wetland water body was conducted. Results indicated that wetland water pollutant concentration higher than the concentration of pollutants in rainfall runoff after the rain stopped. This discrepancy may lie in the following aspects. (1) May is Harbin's spring season period with frequent rainfalls. It drizzled constantly for about a week before May $29^{\text {th }}$ and the pollutants that had entered the wetland was not disposed of in time, so some retained pollutants mixed with the following rainfall-runoff. (2) The selection of the experimental area was not representative enough, because the amount of fertilization of the farmlands in the experimental area was lower than that 
TABLE-2

MONITORING DATA OF WANBAO WETLAND OVER A FEW MONTHS

\begin{tabular}{|c|c|c|c|c|c|c|}
\hline \multirow{2}{*}{$\begin{array}{l}\text { Time and standards for } \\
\text { sample collection }\end{array}$} & \multicolumn{6}{|c|}{ Pollutants } \\
\hline & $\mathrm{COD}_{\mathrm{Mn}}$ & $\mathrm{TN}$ & $\mathrm{NO}_{3}{ }^{-} \mathrm{N}$ & $\mathrm{NH}_{4}^{+}-\mathrm{N}$ & $\mathrm{TP}$ & $\mathrm{pH}$ value \\
\hline October 2004 & 6.31 & 3.12 & 2.05 & 2.52 & 0.157 & 7.03 \\
\hline May 2005 & 7.32 & 5.68 & 4.74 & 0.94 & 0.116 & 6.98 \\
\hline August 2005 & 8.52 & 3.21 & 1.50 & 0.884 & 0.267 & 8.01 \\
\hline April 2008 & 8.32 & 1.77 & 1.344 & 0.092 & 0.205 & 8.97 \\
\hline Class III standards & 20 & 1.0 & - & 1.0 & 0.2 & $6-9$ \\
\hline Class IV standards & 30 & 1.5 & - & 1.5 & 0.3 & $6-9$ \\
\hline
\end{tabular}

of other farmlands. (3) Besides the farmland runoff that flowed into the wetland, the non-point source pollution produced by poultry farming in the neighboring villages around Wanbao county also flowed into the wetland system together with the rainfall-runoff. After 2 days, the rainfall, i.e. May $31^{\text {st }}, 2008$ (no rainfall during these two days), sample collection and monitoring of the wetland water were conducted again and the data showed that the concentrations of total nitrogen, $\mathrm{NO}_{3}$ $\mathrm{N}, \mathrm{NH}_{4}{ }^{+}-\mathrm{N}$ and total phosphorus in the water of Wanbao Wetland all decreased substantially, lower than the concentration of pollutants in the farmland runoff. Total nitrogen was reduced by $74.22 \%, \mathrm{NO}_{3}-\mathrm{N}$ by $50.38 \%, \mathrm{NH}_{4}{ }^{+}-\mathrm{N}$ by $77.94 \%$ and total phosphorus by $17.91 \%$, respectively.

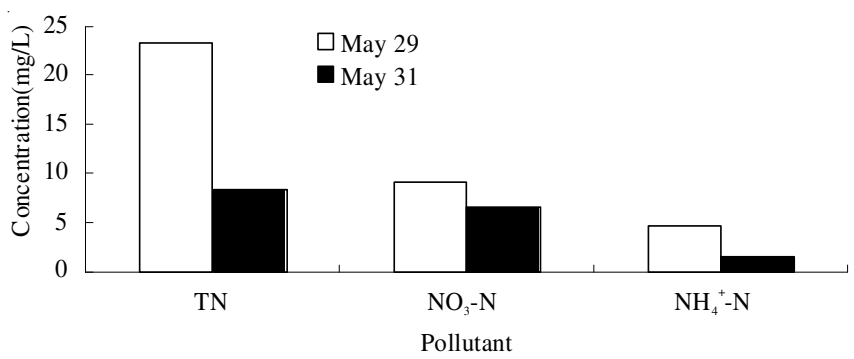

Fig. 3. Change of nitrogen pollutant concentration after 2 days of the rainfall

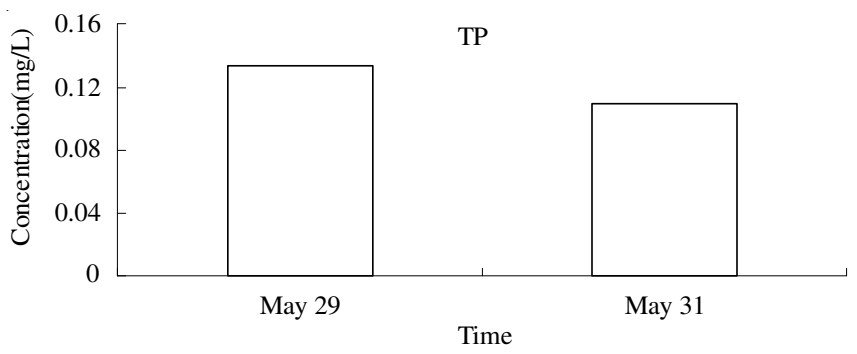

Fig. 4. Change of phosphorus pollutant concentration after 2 days of the rainfall

Seasonal change of non-point source pollutants in the urban wetland: Monitoring data of the water from Wanbao Wetland in different years were summarized in Table- 2 and seasonal changes of pollutants levels were illustrated in Figs. 5-8.

As can be seen in Table-2, the concentrations of both total nitrogen and nitrate nitrogen reached the highest value of over $2.5 \mathrm{mg} / \mathrm{L}$ in May, which may be due to the following reasons. (1) in 2007 and May 2008, two samples were collected at the end of May, when a large quantity of fertilizers are applied after spring tillage and seeding in the northeastern region; (2) starting from late May, the northeastern region gradually enters a period of frequent rainfall; (3) the wetland plants are not thriving in May in the northeastern region, because they are at a stage of recovery, with less plant biomass.
All such factors might cause the high concentration of $\mathrm{NO}_{3}-\mathrm{N}$ in the wetland water in May. The concentration of nitrate nitrogen in the other months is comparatively low, well below $2.5 \mathrm{mg} / \mathrm{L}$, so there is no risk of nitrate nitrogen pollution.

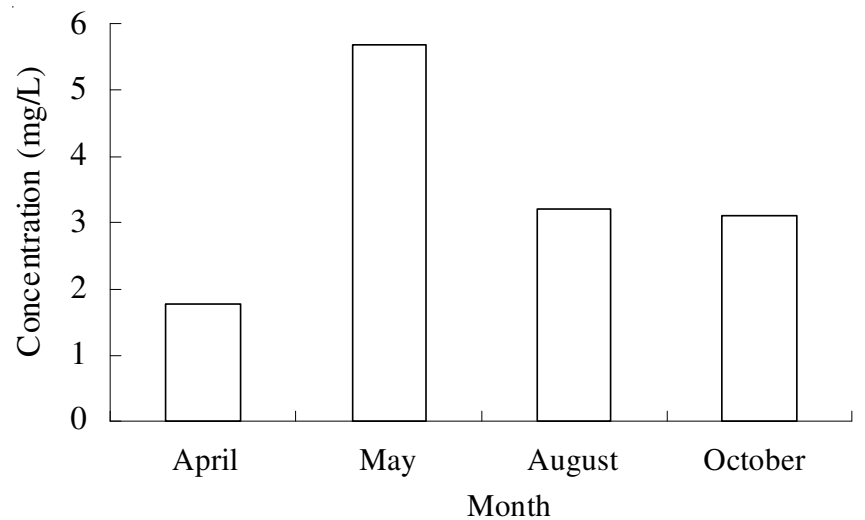

Fig. 5. Total nitrogen concentration in the wetland water body each month

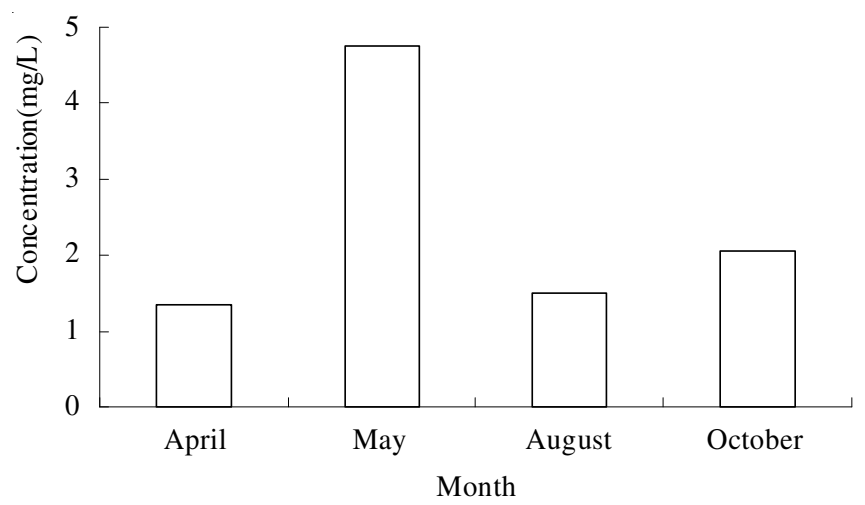

Fig. 6. Nitrate nitrogen concentration in the wetland water body each month

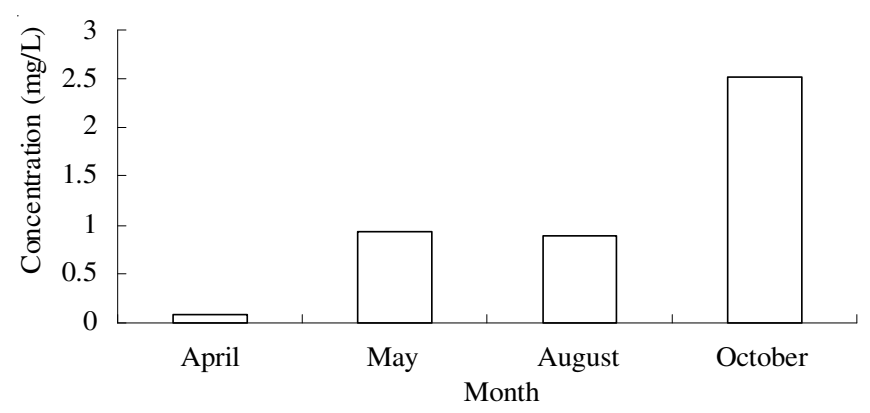

Fig. 7. Concentrations of ammonia nitrogen in the wetland water body each month

The concentration of ammonia nitrogen in the wetland remained lower than the class III standard (Fig.7) except in October 2004, when it was slightly higher than $1.0 \mathrm{mg} / \mathrm{L}$ that 
required by class III standard of environmental quality standard for surface water (GB3838-2002). Therefore, though Wanbao County Wetland has accumulated a large quantity of $\mathrm{NH}_{4}{ }^{+}$ions in the bottom mud, those $\mathrm{NH}_{4}{ }^{+}$ions won't go through further transformation (nitrification) easily when the wetland is flooded, because $\mathrm{NH}_{4}{ }^{+}$features easy absorption and strong release ability, based on which it is inferred that the ammonia nitrogen in Wanbao Wetland has little connection with the ammonia nitrogen pollution of lakes and rivers. As can be seen in Fig. 9, the concentration of total phosphorus in the wetland water was comparatively high, varying from 0.106 to $0.267 \mathrm{mg} / \mathrm{L}$, greater than $0.2 \mathrm{mg} / \mathrm{L}$ required by class III water quality standard but lower than $0.3 \mathrm{~m} / \mathrm{L}$ required by class IV standard in August 2007 and April 2008 and remained lower than class III surface water standard in the rest of the time. This was related to the large quantity of agricultural compound fertilizers application. Wanbao County Urban Wetland has accumulated a large amount of phosphorus during the summer flood season over the years.

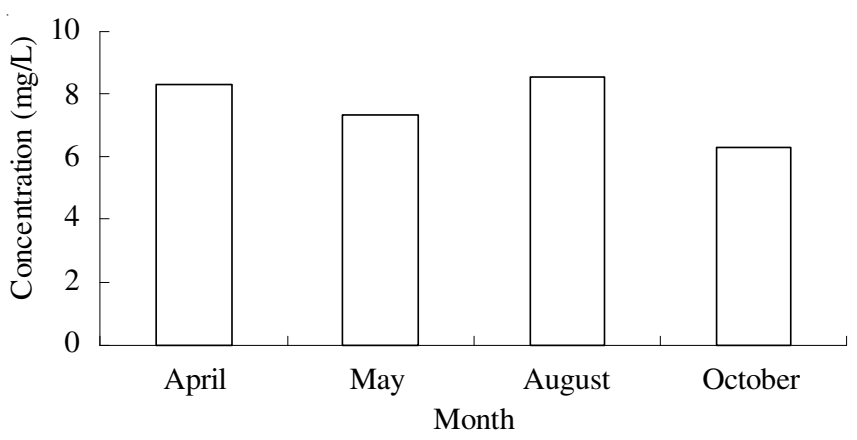

Fig. 8. Concentrations of $\mathrm{COD}_{\mathrm{Mn}}$ in the wetland water body each month

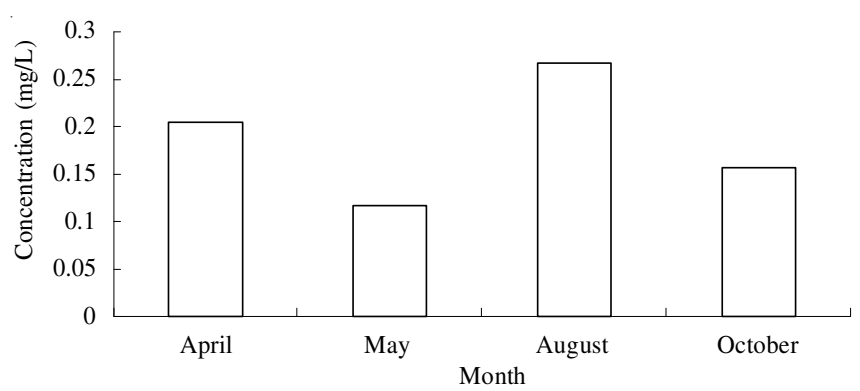

Fig. 9. Total phosphorus concentration in the wetland water body each month

Variation of concentration on rainfall runoff pollution: At beginning, total nitrogen appears high concentration and decreased after $1 \mathrm{~h}$. The total nitrogen top value appears in 55 min and total phosphorus in 25 min after the runoff formation. Total nitrogen concentration of the farm plots is $10.23 \mathrm{mg} / \mathrm{L}$; nitrogen output concentration reaches its maximum $15.81 \mathrm{mg} / \mathrm{L}$ after $50 \mathrm{~min}$. Appear the trend of wave shape change. Total phosphorus initial concentration is $0.88 \mathrm{mg} / \mathrm{L}$ and reaches the highest value $1.14 \mathrm{mg} / \mathrm{L}$ after $20 \mathrm{~min}$. Total output was 0.28 $\mathrm{mg} / \mathrm{L}$ when the rain stopped its concentration decreased significantly.

Much research has done about the runoff pollutant concentration variation on farmland. The trend of dissolved pollutant (nitrate, ammonia and other), concentration change was serrated wave when raining. In normal situation, nitrogen concentration is higher when rainfall runoff and the pollutant. In this experiment, the time we choice is the Heilongjiang Province springs after seeding, fertilizing crops not emergence. So the pollutants concentration results slightly higher than similar research.

Season changes of runoff pollutants concentration in Wetland: The removal rate of nitrogen and phosphorus increased with temperature. Studies ${ }^{28}$ have shown that, short-term temperature change had little effect on nitrogen and phosphorus removal rate, but long term temperature change will lead to the change of N, P nutrients removal rate in wetland. Experimental results ${ }^{29}$ show that temperature has effect on nitrogen and phosphorus removal rate. Low temperature on nitrogen and phosphorus removal rate was lower than that under the high temperature; the temperature influence on the nitrogen was greater than phosphorus.

Our research aims to comparative analysis of nitrogen and phosphorus concentration in wetlands in seasonal change. The data showed that wetland water total nitrogen, nitrate nitrogen concentration in May were the highest over $2.5 \mathrm{mg} / \mathrm{L}$. Nitrogen concentration in wetlands in 2004 October was slightly higher than class III standard $1 \mathrm{mg} / \mathrm{L}$ (surface water quality standard (GB3838-2002)) and rest time is less than III standards. Because the $\mathrm{NH}_{4}{ }^{+}$can easily adsorbed and have strong releasing capability, Wetland nitrogen ammonia nitrogen pollution has little effect on Songhua rivers. Total phosphorus in wetland has high concentration, ranges from 0.106 to 0.267 mg/L, In 2007 August and 2008 April total phosphorus concentrations greater than III water quality standard. The reasons for this as, August crop composite fertilizer in summer season, wetland accumulated a large amount of phosphorus is also an important reason. The wetland sediment accumulation of phosphorus content is higher than that of farmland soil content so the adsorption and deposition is the important way of natural wetland phosphorus removal. But the sediment phosphorus accumulated to a certain extent, the interception ability drops apparently. High concentration of phosphorus in sediment will flow with the change of environment from the sediment release. That is the reason why the phosphorus concentration significantly increases in August. Wetland plants harvested is the effective way to remove the phosphorus as well as improving the capacity of wetland interception non-point source pollutant.

The monitoring data were obtained over a large time span and the selected months (for example May, August) are the periods of a year, when the wetland receives most nitrogen and phosphorus nutrients and other suspended solids from the neighboring farmland runoffs, so the calculation result indicates a pollution degree more serious than that of the wetland in the actual situation. The article aims to determine the efficiency of urban wetlands in removing agricultural non-point source pollutants and meanwhile determine the season-year change law of pollutants in urban wetlands, so the calculation result errors cause by sample collection time are not taken into consideration.

\section{Conclusion}

During the typical rainfall process in Wanbao Wetland, the concentrations of pollutants in the farmland runoff as nitrogen, nitrate nitrogen, phosphorus and ammonia nitrogen 
were very high at the initial runoff formation stage, but began to drop after $1 \mathrm{~h}$. The weak value of total nitrogen concentration appeared about 50 min after the runoff was formed and the weak value of total phosphorus concentration appeared about 20 min after the runoff was formed.

After 2 days, the typical rainfall, the concentrations of total nitrogen, nitrate nitrogen, ammonia nitrogen and total phosphorus in the water body of Wanbao Wetland reduced dramatically. Total nitrogen concentration dropped by $74.22 \%$, nitrate nitrogen by $50.38 \%$, ammonia nitrogen by $77.94 \%$ and total phosphorus by $17.91 \%$, which indicated that Wanbao urban natural wetland in Songbei district has a good agricultural non-point source pollutant intercepting and removing effect.

The seasonal changes of the pollutants in the water of Wanbao Wetland showed that the concentrations of total nitrogen, nitrate nitrogen were the highest in May and comparatively low in the rest months. The concentrations of ammonia nitrogen and COD mn don't vary dramatically, lower than class III standard of environmental quality standard (GB3838-2002); the concentration of total phosphorus was the highest in August and remained comparatively low in the rest months.

\section{ACKNOWLEDGEMENTS}

This research was funded by National Natural Science Foundation of China (No. 51178140), National Creative Research Groups funding (No. 51121062) and State Key Laboratory of Urban Water Resource and Environment (Grant No. 2010DX11).

\section{REFERENCES}

1. W.B. Lyons, P.A. Mayewski, M.J. Spencer and M.S. Twickler, Biogeochemistry, 9, 211 (1990)

2. Y.G. Sun, X.H. Wang and P.S. Yu, J. Prog. Geography, 5, 94 (2004) (in Chinese).

3. K. Jiang, Master's Thesis, Purified Reservoirs and Wetlands Retention Characteristics of Agricultural Non-point Source Pollutants. Hehai University, pp. 7-8 (2006) (in Chinese)
4. L. Verdegem and L. Baert, J. Pedologie, 34, 235 (1984).

5. E.M.A. Smaling and J. Bouma, Soil Use Manag., 8, 44 (1992).

6. H.W.G. Booltink, J. Agric. Ecosyst. Environ., 52, 251 (1995).

7. A.L. Heathwaite and R.M. Dils, Sci. Total Environ., 251-252, 523 (2000).

8. G.L. Harris, Pesticide Loess to Water-A Review of Possible Agriculture Management Opport Unities: Minimize Pesticide Movement. British Crop Protection Council Monograph No 62: Pesticide to Water BCPC, pp. 371-380 (1995).

9. A.B. Davies, R. Joice, J.A. Banks and R.L. Jones, British Crop Protection Council Monograph No. 62: Pesticide to Water. BCPC: pp. 46-52 (1995).

10. R.J. Williams, D.N. Brooke, P. Matthiessen, M. Mills, A. Turnbull and R.M. Harrison, J. Inst. Water Environ. Manag., 9, 72 (1995).

11. L. Shi, B.Z. Wang and X.D. Cao, J. Environ. Sci., 16, 476 (2004).

12. R.M. Gersberg, B.V. Elkins, S.R. Lyon and C.R. Goldman, Water Res., 20, 363 (1986).

13. C.J. Woltemade, J. Soil Water Conserv., 55, 303 (2000),

14. C.J. Woletmade, Potential for Treatment Wetlands to Reduce Non-point Source Nitrogen Loads on a Watershed Scale: Modeling the Conestoga River Watershed, Pennsylvania, USA. Geosciences Research Abstracts, Vol. 7, SRef-ID: 1607-7962/gra/EGU05-A-00344.

15. D.L. Hey, A.L. Kenimer, K.R. Barrett, Ecol. Eng., 3, 381 (1994).

16. G.B. Li, H.D. Zhou, J. China Water Resour., 4, 51 (2003) (in Chinese).

17. G.B. Li, H.D. Zhou and F. Liu, J. The Third World Water Forum, the Third World Water Forum proceedings of Chinese Delegation (2003).

18. J.K. Cronk and M.S. Fennessy, Encyclopedia of Inland Waters, Elsevier, pp. 590-598 (2009).

19. C. Wang, P.F. Wang, J.S. Tang and M. Yang, Adv. Water Sci., 14, 311 (2003).

20. C.L. Jiang, G.B. Cui, X.Q. Fan and Y.B. Zhang, Environ. Sci., 25, 124 (2004) (in Chinese)

21. Q.S. Bao, H.D. Wang and X.Q. Mao, Environ. Sci., 15, 3 (1995) (in Chinese).

22. W.X. Liu, Environ. Sci. Res., 10, 15 (1997) (in Chinese).

23. J.X. Gao and C. Ye, Environ. Sci., 17, 247 (1997) (in Chinese).

24. R.S. Zhang, Q. Zhou and J. Zhang, Environ. Sci., 24, 113 (2003) (in Chinese).

25. R.S. Zhang, Q. Zhou and Y.P. Shi, Environ. Sci., 24, 105 (2003) (in Chinese).

26. C. Wan and S.C. Zhang, J. Hydrol. Eng., 2, 62 (2003).

27. R.H.A. McCuen, Guide to Hydrologic Analysis Using SCS Methods. Prentice Hall, Inc. Englewood. Cliffs (1982).

28. Z.H. Kang, Chengdu Living Water Park in Artificial Wetland and its Three Plant Purification Effect Research. Dissertate for the Master degree of Chengdu University of Technology, p. 36 (2007).

29. M. Borin, G. Bonaiti and L. Giardini, J. Environ. Qual., 30, 1330 (2001). 